\title{
The Role of the Sarva Dharma Ashram in Contributing to the Well-Being of Youth and Their Families in Welbedacht, South Africa
}

\author{
Yashna Gurcharan (D) and Raisuyah Bhagwan* \\ Community Health Studies Child and Youth Care Programme, Durban University of Technology, \\ Durban 4000, KwaZulu-Natal, South Africa; yashnag@dut.ac.za \\ * Correspondence: bhagwanr@dut.ac.za
}

Citation: Gurcharan, Yashna, and Raisuyah Bhagwan. 2021. The Role of the Sarva Dharma Ashram in Contributing to the Well-Being of Youth and Their Families in Welbedacht, South Africa. Religions 12: 1034. https://doi.org/ $10.3390 /$ rel12121034

Academic Editor: John P. Bartkowski

Received: 3 August 2021

Accepted: 25 October 2021

Published: 24 November 2021

Publisher's Note: MDPI stays neutral with regard to jurisdictional claims in published maps and institutional affiliations.

Copyright: (c) 2021 by the authors. Licensee MDPI, Basel, Switzerland. This article is an open access article distributed under the terms and conditions of the Creative Commons Attribution (CC BY) license (https:// creativecommons.org/licenses/by/ $4.0 /)$.

\begin{abstract}
Faith-based organisations act as a powerful source of growth, empowerment and well-being for families in their milieu. This study used a qualitative research approach, specifically a case study design, to explore the role of the Sarva Dharma Ashram in contributing to the wellbeing of youth and their families in the Welbedacht community in South Africa. Three samples, which consisted of 24 participants, were purposively selected. These three samples were made up of the Board members of the Sarva Dharma Ashram, family members who are members of the Sarva Dharma Ashram and community members who live within the milieu of the Ashram. Semi-structured in-depth interviews and a focus group discussion were used to collect data. Following a thematic analysis of this data, the study found that the Sarva Dharma Ashram played a central role in empowering and enabling the wellbeing of disadvantaged family and community members. The ashram not only provided assistance when psychosocial or financial distress was encountered but also highlighted the spiritual support offered to families and other community members in order to transcend the socioeconomic ills they faced as a marginalised community.
\end{abstract}

Keywords: faith-based organisation; family; community; spirituality; social support

\section{Introduction}

The Hindu worldview regards each human being as being Divine and believes that each Hindu can discover knowledge of this truth if they seek it (Nithyananda 2015, p. 1441). Mehta Kalyani (2021, p. 132) asserted that moksha or liberation is everyone's birth right, and accordingly, education, health, or wealth should not be barriers to achieving it. Accordingly, Hindu faith-based organisations strive towards improving the life circumstances of people and are focused on alleviating poverty and its associated socioeconomic ills in an effort to improve the life circumstances of all humankind.

In South Africa particularly, the effects of poverty are more pervasive due to the apartheid legacy. Concomitantly, faith-based organisations have become crucial actors in helping families and youth in marginalised and impoverished conditions. They often play a pivotal role in building a bridge that connects the poor to the nonpoor (Clarke and Jennings 2008, p. 1). In addition to serving disadvantaged families, young people, the ill and other vulnerable members of society (Xaba 2016, p. 5), faith-based organisations also endeavour to meet the spiritual needs of people. These organisations are characterized as nonsecular; therefore, faith underpins much of the functions of these organisations (Du Toit 2019, p. 1). Despite the fact that they play a salient role in spiritual and social development, little empirical research exists which attests to their value in developing contexts.

Hindu faith organisations focus on poverty alleviation, feeding programmes, culture and knowledge empowerment through planned cultural activities, the distribution of religious books and development for spiritual development, and the building of schools 
and homes for indigent families (Sookrajh 2006, p. 68). In this vein, Pandya (2016, p. 23) described a few studies on a Guru-led and Hindu-inspired faith movements' social service programme that benefits the poor. However, the fact given that they are sparse and scattered across disciplines (Pandya 2016, p. 23), created the impetus for the current study. This paper aims to explore the role of a Hindu- faith-based organizationorganisation, the Sarva Dharma Ashram, in contributing to the wellbeing of youth and their families in the Welbedacht community. Welbedacht is a predominantly black township situated on the outskirts of Chatsworth, in KwaZulu-Natal, and is largely disadvantaged, leaving many people to face economic, health and other hardships.

The objectives of the study were to do the following:

(a) explore what problems children, youth and their families faced in the Welbedacht community;

(b) understand the services that the Sarva Dharma Ashram offered children, youth and their families;

(c) explore how families and the community benefited from the organisation, and

(d) understand what collaboration could occur between social services and faith-based organisations to develop disadvantaged communities.

\section{Literature Review}

\subsection{Defining Faith-Based Organisations}

A faith-based organisation has been defined as "any organisation that derives inspiration and guidance for its activities from the teachings and principles of the faith or from a particular interpretation or school of thought within the faith" (Clarke and Jennings 2008, p. 6). Similarly, Crisp (2014, p. 11) described faith-based organisations as "social service agencies which explicitly identify with a religious tradition and/or is any religious organisation or religious community or organisation. Programmes or services offered by a faith-based agency do not necessarily have any religious content." Both these definitions informed an understanding of the faith-based organisation, namely the Sarva Dharma Ashram, within the context of the study.

\subsection{Salience of Faith-Based Organisations}

Historically, faith-based organisations have worked primarily in poor communities, providing crucial services to disadvantaged members of society (James 2011, p. 3). They are an essential part in poverty alleviation initiatives, particularly in developing countries (Olarinmoye 2012, p. 2), and they are responsible for provisioning $30-70 \%$ of health care services in these communities (Hafner 2009, p. 1). These organisations have provided financial and material support to the poor, as well as emergency aid during crises (Tadros 2010, p. 3). Olarinmoye (2012, p. 6) highlighted that development services offered in Nigeria included basic need services, family support services, health services, advocacy, community organizing and development. Faith-based organisations may also be efficient at delivering social services to communities. They have the existing infrastructure, volunteers and resources that could enhance social service assistance (Graddy 2006, p. 131).

Poor communities are largely faith-based communities, and faith leaders often serve as the gate-keepers and opinion-leaders in such communities (James 2011, p. 3). Hence these communities tend to support and trust faith-based organisations. Due to their close proximity to the poor, faith-based organisations are responsive to the issues that they face (Leurs 2012, p. 707). Moreover, these organisations and their staff speak their language and respect their sentiments and culture (Heist and Cnaan 2016, p. 5).

Faith-based organisations also act as a driving force in nurturing the spiritual development of people. Berger (2003, p. 37) wrote that religious nongovernmental organisations are concerned with the spiritual compasses of those they seek to serve. This promotes positive change and transformation of the communities that are facing hardship. Religions around the world highlight faith as a mechanism for coping and resiliency (Heist and Cnaan 2016, p. 3). James (2011, pp. 113-14) highlighted the salience of such 
organisations stating that it enhances the spiritual needs of those they serve, developing values and morals, which may ultimately lead to a sense of hope and purpose.

\subsection{Community Service within the Context of Hinduism}

Hindu religious discourse suggests that Hindus are born with duties that need to be fulfilled. These duties include regular worship, reading of sacred scriptures, practice of rituals, charity in the form of providing food and offering shelter, and praying for one's gratitude and well-being (Sookrajh 2006, pp. 4-5). The concept of sewa is also considered as one of the biggest religious duty in Hinduism. Sewa has been defined as the "selfless act that aims to protect, help, and provide underprivileged human beings and animals without any reciprocation or benefits" (Sewajyoti 2020). This act of sewa is implemented through devotees and followers who form the core constituency of Hindu faith-based organisations (Pandya 2017, p. 4). It is this notion of sewa that underpins the activities of the Sarva Dharma Ashram whose mission is to serve the welfare of the Welbedacht community. The Arya Samaj, the Divine Life Society, the Ramakrishna Mission, Sai Baba Samitis and ISKCON are among some of the many global Hindu organisations which have a support structure to help communities that experience hardship (Sookrajh 2006, p. 2). South African branches of neo-Hindu movements and ashrams grew as more local Hindus became inspired by its teachings and spiritual values (Naidu 2013, p. 142). These organisations premise their work on sacred Hindu texts which state the importance of giving and helping those in need. The Bhagavad Gita, verse 3:20-21 has stated that, "by performing their prescribed duties, King Janak and others attained perfection. You should also perform your work to set an example for the good of the world. Whatever actions great persons perform, common people follow. Whatever standards they set, all the world pursues" (Swami 2014). This translation urges Hindus to act selflessly for the welfare of others. It does not only refer to financial support but also includes all areas where support can be provided to those who are less unfortunate.

\subsection{Roles of Faith-Based Organisations}

\subsubsection{Spiritual Upliftment}

Faith-based organisations serve as a driving force in the spiritual development of its people. Most organisations are underpinned by values and principles that are linked to the religious worldviews and their teachings. Justice, compassion, reconciliation, care and forgiveness are some of the instrumental faith-based morals and values that form the basis of the spiritual and religious teachings of these organisations (James 2011, pp. 113-14). Often faith-based leaders are in a pivotal position to influence and guide people with regards to such teachings. Several Guru-led and Hindu-inspired faith-movements have tailor made programmes for children and young people, with the aim of cultivating their religiosity and spirituality so as to enhance their holistic wellbeing (Pandya 2016, p. 26).

\subsubsection{Food Programmes}

The United Nations Population Fund (UNFPA (United Nations Population Fund) 2015, p. 41) indicated that "health and nutrition are areas of development, with the longest and best-documented tradition of faith-based engagement." Religious places of worship and their congregations are often involved in various forms of development work such as providing the poor with food. Marginalised communities most commonly endure food deprivation. The sacred Hindu text, the Bhagavad Gita speaks of niskhaam karma which means non-attachment to the material world and service rendition to all. The provision of food to the poor is regarded as the highest form of social service and acts as a means to reach out to the wider community, through faith in action (Pandya 2017, p. 18). Hindus believe that providing food to the poor and disadvantaged is a noble deed which helps their spiritual growth (Sookrajh 2006, p. 14). They also believe that those who provide food attain great happiness (Klostermaier 2000).

Hindu-inspired faith-based organisations in India have also adopted strategies to promote social service or sewa (to serve) (Pandya 2017, p. 4). The International Society for 
Krishna Consciousness (ISKCON) is an organisation of such a nature and has developed the ISKCON Food Relief Foundation (Pandya 2017, p. 6). One of their earliest initiatives was the Food for Life programme, run by ISKCON in the England, where food was distributed to homeless and hungry people (Pandya 2017, p. 6). This programme has also been operational in several other countries around the world. The Hare Krishna Movement of ISKCON has its roots in the teachings of the Hindu Lord Chaitanya, who was seen as an incarnation of Krishna and Radha (Krishna's divine lover and consort) who collectively possessed a metaphysical form with human traits (Pandya 2017, p. 4). Food became a way to serve, not just the Lord, but also to further the mission of the Guru Srila Prabhupada. Food is representative of their Food Relief Foundation, of "both the naturalistic and the spiritual, a vehicle which permits the survival of humanity as individuals and as a species" (Pandya 2017, p. 17). This is tied up with the work of many Hindu faith-based organisations.

\subsubsection{Educational Upliftment}

Faith-based organisations have also been known to support the educational goals of schools. Nishimuko $(2009$, p. 291) stated that the role of faith-based organisations in Sierra Leone have contributed to informal education by (1) accessing vacant land for building schools; (2) rehabilitating neglected schools; (3) providing support resources such as transportation, equipment and teaching materials when needed; (4) providing scholarships for teachers to study; (5) and providing scholarships for pupils. Many Hindu organisations fulfil this form of service through the distribution of books and the building of schools in disadvantaged communities (Sookrajh 2006, p. 16).

\subsubsection{Psycho-Social Support}

Faith-based organisations are also well positioned to provide psychosocial support and care to children and their families in a community. Psychosocial support can be described as "a continuous process of meeting emotional, social, mental and spiritual needs, which are considered vital elements of meaningful and positive human development" (Hlalele 2012, p. 63). The religious sector is well positioned to provide counseling and skills training with regards to marriage preparation, enrichment and parenting. In addition, faith-based organisations can establish and strengthen social networks between families. Moreover, the presence of these religious organisations can create a more stable and trustworthy environment for families (Harr and Yancey 2014, p. 151). Pandya (2016, p. 29) wrote that the presence of Guru-led and Hindu-inspired faith movements in the social service milieu enables tangible social service projects, as well as spiritual programmes aimed for the psychosocial benefits of its followers and beneficiaries.

\subsection{Spiritually-Based Activities Implemented at Hindu Inspired Faith-Based Organisations}

\subsubsection{Prayer and Devotional Singing}

Prayer is understood as "an act of addressing God with reverence, offering praise, giving thanks, affirming and confirming one's total dependence on God, and asking for His grace, mercy, and help" (Ahsan et al. 2012, p. 168). Prayer can be done either as an individual practice or communally, and it takes place in a public space or in a private environment. It may involve the use of words or song (Anand 2014, p. 6). Indian music is deeply grounded in the theological principles of sacred sound as contained in Hindu scriptures (Beck 2019, p. 2). Prayer also gives people a sense of comfort and guides people to address their problems. Bradshaw and Ellison (2010, p. 5) asserted that religious involvement often helps families cope with socioeconomic deprivation. Given the latter, families facing economic difficulty tend to have increased levels of distress due to unstable relationships, financial constraints, physical limitations and unsafe neighbourhood conditions. Hence, prayer acts as a source of healing and comfort to the community. As such, faith-based organisations act as a space for communal worship and prayer. Faithbased organisations offer communal prayer which can benefit individual wellbeing and 
personal spirituality (Piraino et al. 2014, p. 1). It is not surprising to find, then, that faith-based organisations integrate faith practices such as prayer into their activities with families and the community (Moyer et al. 2012, p. 15; Johnsen 2014, p. 415). An article by Naidu (2013, p. 143) described the occurrence of the annual yajna (prayer), which is a mass sacrificial offering and oblations fire ritual for universal peace. It is conducted by a priest with devotees and community members.

\subsubsection{Scripture Reading}

Nordtvedt and Chapman (2011, p. TAHP6) wrote that key teachings in religious books hold a strong basis for wellness at faith-based organisations. They indicated that all religious teachings shared common values which are promoted across different faiths. Kaur and Gupta (2013, p. 27) highlighted that all scriptures have one commonality, and that is to teach ethics, values and attitudes applicable to all human beings and aim for a just and harmonious society. In Hinduism, the sacred scriptures are embedded in the Ramayana, Mahabarata and the Bhagavad Gita. These texts share epic tales of noble deeds and form the basis of Hindu spiritual values (Laungani 2005, p. 140). The teachings embedded in these sacred texts also embody common universal values (Kaur and Gupta 2013, pp. 28-29). In the same vein, James (2011, p. 113) indicated that faith teachings often highlight development principles, such as fairness, empathy and harmony. Religion and religious teachings may also foster prosocial behaviour, coping skills, a sense of purpose and identity development amongst youth (King and Boyatzis 2015, p. 978).

\subsection{Integration of Social Work into Faith-Based Organisations}

The collaboration between the faith-based and social work sector presents the opportunity for families to receive social services, thus enabling family strengthening and preservation, which is crucial in under-resourced and disadvantaged communities. Pandya (2016, p. 23) argued that collaboration between faith-based organisations and social services enables the provision of psychosocial support to poor families. Social workers often undertake therapeutic work with families and children when stressful situations occur (Seden 2011, p. 60; Spray and Jowett 2012, p. 49) and are expected to offer support through promoting change, conflict resolution, empower people and improve their well-being (Algate 2011, p. 134; Glicken 2011, p. 12; Monnickendam et al. 2010, p. 918; Spray and Jowett 2012, p. 21). Many of the roles interface with those of faith leaders and are at the core of faith-based organisational work (Garland and Yancey 2012, p. 313). This is where collaboration can occur.

\section{Methodology}

\subsection{Qualitative Approach}

This study was guided by a qualitative research approach, specifically a case study design. A case study is "an intensive description and analysis of a phenomenon or social unit such as an individual, group, institution or community" (Merriam 2002, p. 8). The case in this study was the Sarva Dharma Ashram, a faith-based organisation in the Welbedacht community, in the Province of KwaZulu-Natal, South Africa. Crowe et al. (2011, p. 1) wrote that a case study approach is particularly useful when there is a need to obtain an in-depth appreciation of an issue, event or phenomenon of interest in its natural, real-life context. Therefore, the purpose of the case study was to explore the role of the Sarva Dharma Ashram in uplifting and enabling families and community members within its milieu.

\subsection{Study Setting}

Welbedacht is a predominantly black township where poverty, economic hardship and other associated social ills are prevalent. The community occupy low cost houses and are challenged by a lack of service delivery from the government. The Sarva Dharma Ashram has been operational for 27 years in Welbedacht. It arose from an awareness that despite this being a disadvantaged community, it lacked a spiritual support system and was without health and social service delivery. The ashram began as a small infrastructure and 
has since grown extensively and is now able to accommodate 400 people. Youth and their families from all racial backgrounds in both Welbedacht and neighbouring communities attend the ashram regularly, for both social and spiritual support.

\subsection{Background of the Sarva Dharma Ashram}

The Sarva Dharma Ashram was founded in 1997 by Swami Ramkripananda Saraswati, a monk initiated by the world-renowned Swami Sivananda Saraswati of the Divine Life Society which is based in Rishikesh, India. Swami Ramkripananda moved to South Africa, where he devoted his life to serving the Welbedacht community in KwaZulu-Natal. After identifying Welbedacht as a community in need, the Sarva Dharma Ashram was built within its milieu and was underpinned by Hindu principles to serve, love and give. Swami Ramkripananda leads a simple life similar to other Hindu swamis who dedicate their lives to the betterment and upliftment of those in need. The philosophy and spiritual values of Swamiji are similar to those of most other swamijis of other Hindu organisations. Most spiritual leaders of Hindu organisations are committed to promoting "sewwa," which means to serve the needs of the poor as part of their spiritual journey.

The Sarva Dharma Ashram evolved into a registered nonprofit organisation and became affiliated with the Divine Life Society, which is a large-scale organized charity movement. This organisation relies heavily on funding provided from donors, businesses and other fundraising initiatives that is used to uplift the needy. Hence much of the service provision is through donations. In terms of the labour, the Guru or spiritual leader of the ashram, together with other board members of the ashram who are also spiritual leaders are responsible for offering spiritual services and activities. The other activities related to the provision of meals, health camps and other upliftment projects are undertaken by volunteers from across the eThekwini region in KwaZulu-Natal. Most Hindus and other religious groups are charitable in nature and are strongly influenced by a sense of religious and civic responsibility towards community needs (Sookrajh 2006, p. 23). Those who cannot donate often volunteer their time to preparing meals and dedicate time to become involved in social upliftment projects.

Although the Sarva Dharma Ashram evolved within a Hindu context, most of those who attend the ashram come from non-Hindu backgrounds. Essentially, the ashram was developed to create a universal space which was welcoming of people from different religious or cultural backgrounds. Most of those who attend the ashram are those who live within the Welbedacht community because this community is located a distance away from other townships. The ashram emerged because it is a socially marginalised community. Many African isiZulu and Hindu families who live in Welbedacht attend the ashram. Those who provide sponsorships and donations also attend spiritual service whenever possible. Attendance and the social support provisioned is not premised on the religious affiliation of any member. Those African families who chose to attend Hindu services are provisioned with scriptures that are in isiZulu to understand the meaning of it. In this vein, Kaur and Gupta (2013, p. 27) argued that all religious scriptures reflect universal ethics and values, such that all human beings are more tolerant of and strive towards a more peaceful society. The Sarva Dharma Ashram's teachings are universal in nature. Hence spiritual and social service provisioning is nondiscriminatory in nature. Hence, regardless of the religious faith of members of the Welbedacht community, they all benefit from donations and other health and upliftment projects. Moreover, as indicated by the spiritual leaders who were interviewed, donations were received from people of all religious backgrounds who recognised that the ashram served everyone in the Welbedacht community and did not restrict their spiritual and social programmes to those solely who were Hindus. The spiritually based activities offered by the ashram, such as yoga, playing musical instruments and meditation, are not intended to convert members to Hinduism but to enhance health and well-being. These activities were seen as salient within the context of the huge stressors being faced by the community. Those wishing to attend devotional service do so voluntarily and are given the opportunity to understand Hinduism better. 
However, at no point does the ashram discriminate or withhold the provision of its feeding, health and social upliftment activities to any person based on their religious background. The activities and services provided at the ashram are discussed further in the findings and discussion section.

\subsection{Demographics of Participants}

There are approximately 7311 inter-racial families residing in Welbedacht. However most families are predominantly Black South Africans. A small sample of 20 Black South Africans participants were recruited for the study. The Hindu participants recruited for the study are made up of 1 individual who immigrated to South Africa and the remaining 3 participants who are South African Indians.

\subsection{Sampling}

Nonprobability sampling methods (specifically purposive sampling) were used to select three samples for the study. Sample one consisted of family members, namely parents or grandparents; sample two included the board members of the Sarva Dharma Ashram; and sample three was community leaders in the Welbedacht community. Following an email to the Head of the Sarva Dharma Ashram asking him for permission to conduct research at the ashram, a gatekeeper's letter was obtained from him. The Head of the Sarva Dharma Ashram played a pivotal role in accessing the community because he is well known figure to community members. He introduced the researcher to the community and helped to recruit and set up interviews with those who gave their consent. In total, twenty-four participants were recruited and data collection stopped after saturation was reached. Ten African parents or grandparents, ten African community members and four board members of the ashram were interviewed for this study. Data was collected using semi-structured interviews for the parents and community members and a focus group discussion was used for the board members. A pre-tested interview guide was used to guide the interviews. All three interviews were digitally recorded and then transcribed verbatim. Thematic analysis was used to analyze the data collected. Thematic analysis is the process of identifying patterns or themes within qualitative data. It is a flexible approach and produces rich and detailed data (Braun and Clarke 2006, p. 6).

\subsection{Ethical Considerations}

Ethical clearance was obtained from Durban University of Technology's Institutional Research Ethics Committee (IREC). The ethical clearance number for this study was IREC 191/18. Permission to conduct research was also obtained from the Sarva Dharma Ashram. Reflexivity was achieved by keeping a reflective diary and through debriefing with the supervisor. Moreover, trustworthiness was achieved through member checking of the data and through the triangulation of data collected from the different samples.

\section{Findings and Discussion}

There were four themes that emerged from the data. The data was analyzed holistically across all four samples and will hence be presented holistically.

\subsection{Theme 1: Poverty and Hardship}

Participants reported that poverty, food insecurity, substance abuse, crime and a lack of service delivery collectively contributed to hardship amongst families and in their community. They said the following:

"The biggest problem is the financial state in our homes ... we are unemployed and our husbands are also not working ... sometimes we had to sleep on an empty stomach as we cannot afford to buy food for ourselves and our children".

"A few times I had to beg for food from my neighbours because the money was finished and I have two children to care for ... I am also illiterate I cannot find a job because I have no skills". 
"The majority of people live in shack houses and others are homeless".

"Teenage girls from a young age are introduced to alcohol and drugs and are dating married and older men just to get money to buy it. They get drunk and do not protect themselves and end up with HIV / AIDS and also abort the unborn baby ... they have become prey to older men referred to as blessers".

These excerpts reflect the extreme hardship being faced, particularly food deprivation. One participant said that she sometimes slept on an empty stomach or had to beg for food, while another said that financial deprivation due to unemployment had left her unable to provide for her children's needs. Poverty is a complex and multidimensional phenomena that creates multiple stressors that disrupts the well-being of people (Ebenezer and Abbyssinia 2018, p. 235). In South Africa, poverty is synonymous with the history of disadvantaged non-whites through the apartheid regime. Although the country has undergone various transitions over the last two decades, systems introduced by apartheid continue to perpetuate high levels of poverty, inequality and low levels of opportunities (Sekhampu 2012, p. 146), as apparent in the current sample. Poverty is more prevalent in townships because many of them are situated in underdeveloped urban living areas (Sekhampu 2012, p. 146), such as Welbedacht. Shisana Olive et al. (2013, pp. 145-46) found, in 2012, that the largest number of participants who experienced hunger were from informal localities. This reflects findings made in the current study, as Welbedacht is an informal setting.

Substance abuse was also identified as a problem in the Welbedacht community. Substance abuse is known to contribute to a range of issues such as increased school dropout, unemployment, a high level of crime and other negative health and psychosocial sequelae amongst adolescents (Thobejane and Raselekoane 2017, p. 94). Participants expressed that the poor socioeconomic conditions and a lack of social support had caused youth to engage in antisocial and risky behavior. One participant reported that many youths in the community had dropped out of school and resorted to petty criminal acts to satisfy their cravings for drugs and alcohol. Another participant noted the presence of 'blessers' in the community, who attract young women to indulge in risky behaviour. Blessers are older rich men who entice young women with money and expensive gifts in exchange for sexual favours (Mampane 2018, p. 1). The misuse of substance coupled with risky sexual conduct increases the risk of developing sexually transmitted diseases and HIV / AIDS (Cooper et al. 2015, p. 62). Participants expressed concern that young girls in their community were engaging in such risky behaviours with "blessers" in order to fund their need for alcohol and drugs.

Participants also reported that crime was rife in Welbedacht and ranged from small criminal acts such as mugging to serious crimes such as murder. Cooper et al. (2015, p. 62) explained that experiences of violence are "shaped by age, gender, socioeconomic status and geographical location". This is true of the Welbedacht community where poverty and other social ills form breeding grounds for violence and crime. Moreover, as De Wet et al. (2018, p. 2) stated, exposure to crime and violence in families and communities leads youth to become victims and perpetrators. Accordingly, youth, who are exposed to crime and violence in the community, may feel that it is the norm to do so and start to engage in it themselves. Participants reported that there are many "tsotsis" in the community. "Tsotsis" are thugs who are found in predominantly Black South African townships (Letsela and Ratele 2009, p. 1).

In this vein, one participant said that "there are gangs around here, it's not safe to walk alone ... but there are also no police around to safeguard us".

A major responsibility of the government is to deliver services that a society requires to maintain and improve its welfare. It remains as an important feature in poverty reduction strategies. South Africa's response to provide health services to the poor has resulted in the introduction of local health clinics, situated in communities (Grut et al. 2012, pp. 5-6). However, communities such as Welbedacht do not have a clinic in close proximity to their neighbourhood, as presented below. Coovadia et al. (2009, p. 825) indicated that the cost burden on households seeking access to health care services placed such households in 
a difficult financial situation. This clearly spells out the realities that participants have experienced in Welbedacht, due to the lack of health services. Another issue was the lack of visible policing and a lack of a nearby police station in the community.

"The clinic that was at the ashram had a positive effect on the community. It should run 5 days a week but it closed down because it was becoming too costly to maintain, the water bill was high. It became too costly and no funds from government".

\subsection{Theme 2: Services Offered by the Sarva Dharma Ashram}

The data reflected that the Sarva Dharma Ashram has played a pivotal role in addressing the basic need for food, through its feeding schemes in the community and at schools in the area. This is part of the ashram's poverty alleviation strategy in and around Welbedacht. According to one of the board members who was interviewed, 21,000 vegetarian meals are served every week, 5000 school sandwiches are prepared per week, and half a ton of fruit is distributed per month. Both the family members and community members interviewed also reported that the school feeding schemes helped in providing nutritious food to the children who endured deprivation.

A participant said, "I actually cried to see how children are running. Small children, like about three years, four years running with the containers for food. They follow the long line and we start serving them food. We had our boys to help us. And they listen, and they get food. They have it and they go home with a container full of food".

In this vein, The United Nations Population Fund (UNFPA (United Nations Population Fund) 2015, p. 41) argued that "health and nutrition are areas of development with the longest and best-documented tradition of faith-based engagement". Faith-based organisations have therefore been lauded for the important role they play in community food programmes (Power et al. 2017, p. 460). One participant described the day when she went to deliver food to the community. She said, "I went down with them to serve food ... I couldn't believe what I saw. Children were running with empty containers, pots, ice cream containers. They saw the van coming down. That excitement of food ... and now everyday food is being cooked so they can have it".

The study found that medical health camps were also provisioned by the ashram. These camps form an effective way to provide health education and awareness to the community, with regards to the importance of health, as well as to spread sound advice and information about lifestyle choices (Pandey et al. 2011, p. 87). The provision of medical health camps was reported to be beneficial to the Welbedacht community because there is no clinic that is within close proximity. Participants said that there were huge transport costs associated with taking a taxi to the local hospital, and they were not guaranteed that they could consult with a doctor because of long queues and patients being turned away. The provision of the clinic and health camps which created access to doctors and other medical staff was important. As one community member reported, "the hospitals are too far to reach ... even the ambulance takes its time to arrive at an emergency here".

Faith-based organisations have a rich history of proving healthcare particularly in areas where such services are inadequate (Kagawa et al. 2012, p. 1). They are considered to play an important role in strengthening health systems and ensuring access to healthcare in developing countries (Kagawa et al. 2012, p. 1), as evident in the current study. Bopp et al. (2012, p. 52) further noted that health promotion interventions undertaken at faith-based organisations have been hugely beneficial in promoting health services in under-resourced areas. The Sarva Dharma Ashram had an on-site clinic to the community, which had benefited the elderly in the community because it was easily accessible. The challenge associated with sustaining the clinic, however, was evident in the following excerpt: "the clinic service was offered for many years at the ashram but it had to be stopped because the expenses escalated (and), the provision of that service here was beyond the ashram's capability". This excerpt exemplifies the common challenges faced by most faith-based organisations, namely funding to ensure sustainability of their services. 
Despite the clinic being a valuable entity within the community milieu, as one participant said, "it had to be stopped because the government won't fund it".

Another important service provisioned by the ashram was support towards school needs. A board member said in an interview that a substantial amount of money was set aside annually for stationery, uniforms, other school apparel and school fees for learners in the community. Nishimuko (2009, p. 284) asserted that community faith-based organisations support education by sensitizing individuals to the importance of schooling. A major research project titled, "Access to Education in South Africa," undertaken by Strassburg et al. (2010, pp. 17-27), found that poverty-stricken households often cannot bear the financial burden of buying school-related resources and transport costs. Faithbased organisations often support education in under-resourced communities through school construction, by providing scholarships for teachers and students, by providing teaching and learning resources, and by recruiting teachers (Nishimuko 2009, p. 291). Participants expressed "huge relief" and gratitude that the ashram provided school tuition, especially tutorship on mathematics. The presence of after-school tutor programmes have been found to act as a significant contributor to the improvement of children's school performance, within the context of faith-based organisations who provide same for youth in disadvantaged communities (Green-Powell et al. 2011, p. 66). For the children and families who endure financial hardship, commuting outside of the community to secure tuition would be impossible. The provisioning of school stationery for underprivileged children occurred as follows:

"We got all the children's ages and what grade they in so we know what grade they will be in next year, so we get a list of stationery requirements ... and hand out to the children in January".

The study also found that the ashram offered youth development programmes for children and youth in the community. School support is combined with other educational and life skills programmes aimed at youth development. These include computer classes, yoga, and art and drama lessons. This suggests that the ashram is youth oriented and endeavours not only to provide educational upliftment initiatives but also holistic well-being programmes and life-skills empowerment activities. Youth building and empowerment programs are crucial to developing disadvantaged youth (Larson and Ngo 2017, p. 3). Faith organisations can make a powerful and positive difference in the lives of youth by serving as a safe haven for homeless youth and by engaging them in social and educational activities to contribute to their learning (McLaughlin 2000, p. 6). Youth who participate in faith-based activities have been reported to have more positive identity, higher emotional regulation, interpersonal development, positive relationships and connection to adults (Larson et al. 2006, p. 860). Therefore, the programmes offered by the ashram can enhance resiliency amongst youth, and it enables them to connect with others to build positive relationships (Roth and Brooks-Gunn 2017, p. 189).

Moreover, religion and spirituality have been found to play an important role in youth development, with research supporting its relationship with enabling thriving (Cheon and Canda 2010, p. 123). It has been found to protect adolescents from negative behaviours, promote health-related outcomes and prosocial behaviour (Furrow et al. 2004, p. 24). Youth who are involved in faith-based and religious activities have been found to display positive behaviour and values (Kvarfordt and Herba 2018, p. 154).

This was evident amongst the youth attending the Sarva Dharma Ashram, despite their impoverished circumstances. One participant said that "Swamiji is always encouraging and supporting the youth to make their futures a success ... if there was no ashram here then there is no one here to stand with our community".

The study found that youth from the surrounding community were active participants in religious activities at the ashram. This also created the opportunity for them to be selected to attend and perform at a religious event in India. The most important finding was that the Sarva Dharma Ashram was open to youth and families from diverse ethnic backgrounds. Hence, despite it being a Hindu organisation, there was no religious discrimination in 
terms of providing support and attendance at the different activities being offered at the ashram. Regardless of their religious affiliation, the focus of the ashram is developing the strengths of youth in their milieu.

A participant said that "the vision of the Sarva Dharma Ashram is to expand its services into this community and to further concentrate on youth development so that we can improve the livelihoods of people in the future".

The community refer to the spiritual Head of the Sarva Dharma Ashram as their "Swami" or "Guru" as a form of respect for him. Singh (2016, p. 78) described a Guru as the epitome of wisdom, knowledge, self-control, simplicity, compassion, purity, kindness, bliss, and love. Dressed in traditional attire, children and families engage in singing melodious and powerful spiritual songs, as the Swamiji conducts regular satsangh programmes at the ashram. Jacobs (2014, p. 881) described a satsangh, as a traditional Hindu practice which is prevalent in many contemporary Hindu ashrams and has a congregational aspect. It begins in the company of the Guru and a group of devotees who gather together for devotional purposes (Jacobs 2014, p. 881). Families congregate together and worship in the form of chanting, devotional singing, reading of sacred texts and yoga practices. This communal participatory activity which takes place regularly at the Sarva Dharma Ashram helps keep youth away from negative influences and provides religious support to families experiencing distress. Participants expressed that during the satsangh programme, they feel peaceful and happy and they learn many spiritual values which they are able to inculcate in their children as part of their moral upliftment.

One participant said that youth "at the satsangh have the vibe and positive energy to sing and pray at such a young age ... it's beautiful".

Another said, "on Sundays when Swamiji is speaking at the satsangh. I go home and discuss it with my children so they know what is wrong and what is right".

These spiritual activities are beneficial to family well-being. Bhagwan (2012, p. 241) described these spiritually oriented practices and others such as the reading of Hindu scriptures, prayer, rituals, yoga and meditation as powerful protective factors that promote individual and family well-being. Benson and Roehlkepartain $(2008$, p. 16) noted that there are specific contexts, practices, and experiences that cultivate spiritual development. These include mindfulness meditation, prayer practices and yoga, and other Eastern traditions; sacred music or religious scriptures; chanting, the use of prayer beads or a mantra; or rituals such as lighting an incense (Walsh 2012, pp. 360-61). These encapsulate the range of spiritual activities that children and their families engage in at the ashram and are encouraged to practice in their homes. For most Hindus, this human interdependence and spiritual interconnectedness that exists within faith-based organisations is the foundation of their wellbeing. Written spiritual sources of strength can be sought and found in a variety of places (Apostolides 2017, p. 3), which includes faith-based organisations, ashrams or homes which have a space to pray in. Practice of the spiritual activities described, enables greater spiritual well-being amongst people, which in turn enables them to cope with everyday stresses, by giving them hope and meaning in life (Bhagwan 2009, p. 226).

The Sarva Dharma Ashram has also played a salient role in providing women with entrepreneurial skills that have empowered them to start their own small businesses.

Oghenekohwo and Tonunarigha $(2019$, p. 197) stated that empowerment programmes implemented by faith-based organisations are often self-sustainable and can be replicated. They also provide candidates of such empowerment programmes, with economic development information and resources to enhance their growth process. The Sarva Dharma Ashram is home to an Empowerment Center. A sewing programme was initiated which can be regarded as self-sustainable because the community members who completed the course have received sewing machines and have been provided with economic education to help them start their own businesses. Of significance is that they have been able to support their families from the income that they receive.

Participants said the following: 
“There is a women's group that takes place here that they meet regularly so that they can share skills".

"At the Woman Empowerment Centre, is where the sewing classes take place and whoever graduates receives a certificate and a brand new sewing machine to take home".

Participants also reflected on the nature of other social and emotional support received at the ashram. This ranged from helping youth who do not possess an identity document to secure one and also practical assistance for children to obtain passports. The latter was necessary as the organisation facilitated the opportunity for disadvantaged children and youth to perform internationally, at a religious event.

Moreover, the Sarva Dharma Ashram was found to be described as a space where community members could receive spiritual counseling. Participants reported that they could receive advice and support from the ashram's spiritual head. Other studies by Yancey and Atkinson (2004, p. 254) found that the urban poor felt cared for, treated as significant and valued as a person, through the provision of social counseling services at faith organisations. One participant described that that she felt she was part of the ashram because she is treated with love and respect whenever she visited the ashram.

Many faith-based organisations are known to play a crucial role in providing spiritual support in terms of the hardship they experience (Tadros 2010, p. 22). This was also evident at the ashram as members reported receiving emotional support when faced with difficulties. One participant described the impact of the loss of a loved one saying that the faith leaders visited the family often and provided them with emotional support.

Other participants said the following:

"We receive a lot of love filled with joy and compassion. Everyone you see here shows you love".

"The ashram is our pillar of strength".

"Members of the community come to the ashram and discuss their issues with Swami when they have issues such as marital problems ... instability in their homes. Some of the youth come from broken homes and sometimes they stay at the Ashram when their family is experiencing problems".

As is evident, the ashram is a space for spiritual support and counseling. Bhagwan (2012, p. 239) concurred, saying that "sacred sites such as temples and ashrams provide refuge for those in distress and are believed to heal those who make the journey to these divine places". This was evident in the following excerpts, with participants saying, as follows:

"When I am at the ashram ... I feel very full spiritually".

"When I am upset I come to the Ashram and pray ... I feel much better thereafter".

Hence not only do devotees experience emotional and social support, but they are also able to grow spiritually.

\subsection{Theme 3: Role of the Spiritual Leader at the Organisation}

As discussed above, participants refer to the spiritual head of the Sarva Dharma Ashram as "Swamiji" whilst other participants call him their "Guru". These two words essentially have the same meaning in Hinduism, and when translated simply, they refer to teacher. According to UNICEF (2012, p. 4), religious leaders have a moral authority and are able to influence thinking, foster dialogue and set priorities for members of the community. They are often the first to respond within the community, and this is why they have gained the trust of families and communities. As such, spiritual/religious leaders act as a role model towards families and youth because they are able to set positive examples for the community. The spiritual head of the Sarva Dharma Ashram's role as a teacher is to instill good values amongst the children and their families alike. Participants described how this happens as follows: 
"When Swamiji is speaking, he teaches us what is wrong and what is right. He shares his knowledge with us. Swami is wise ... there is no discrimination here. Only love, support and care. He uplifts us when he speaks because he gives us motivation to be the best".

"The most time I value is when Swamiji tells us stories and in a way that helps build my self-esteem".

Participants said:

"We are concerned with faith, but at the same time we are concerned with life, and life is about living the right way".

"Our children learn a lot from Swami. They get to learn how to chant and to read the holy books like Bhagavad Gita".

There is a range of factors that make the Sarva Dharma Ashram a special place for participants. This includes positivity, respect, love, dignity, discipline, and respect for all religious groups. The ashram is welcoming of different racial and ethnic groups. These are evident in the aforementioned excerpts which reflect that the ashram resonates love, care and support. Chima (2015, p. S4) argued that faith-based organisations should not be used to induce intolerance and incitement against other religious worldviews. The data reflected that the ashram respects diversity and welcomes people from all faiths. Participants mentioned that everyone is treated equally and benefits equally. Some affirmed that regardless of their other own other religious faith, they still come to the Sarva Dharma Ashram because everyone is accepted, loved and provisioned with food hampers and everyone benefits from the initiatives offered.

Participants said as follows:

"The value system extending from this Ashram is quite basic, practical and should be easy to grasp. It's about trying to ensure they stay on a straight and narrow path;"

and

"The Sarva Dharma Ashram is a universal place".

Children often have first encounters with religious settings such as the mosque, church and temple. In these first points of contact, children are able to explore their religion and are also taught social behaviour such as morals and values. The Sarva Dharma Ashram plays an important role in nurturing these values without pressure to change their faith. Youth also engage in multiple spiritually based activities such as learning to playing musical instruments, such as the drums, and singing different hymns. Sunday is the biggest day at the Sarva Dharma Ashram because there is a special programme for all. During the Sunday programme, youth and their families pray together and have the opportunity to listen to the inspirational discourses made by the spiritual leader of the ashram who shares his wisdom and knowledge related to positive living and well-being.

One participant said that they enjoy the Sunday programmes as the youth learn about the Bhagavad Gita, which is a holy book for Hindus. The aim of the teachings within this sacred text is to give individuals a sense of purpose, promote an ethical way of living and provide comfort to the distressed. One of the principles underpinning the philosophy of the Bhagavad Gita is karma yoga, which means 'path of union through action.' It signifies the promotion of selfless actions and the nondiscrimination of people (Srivastava et al. 2013, p. 4). This is in line with the teachings of the spiritual head as he engages with youth and explains the significance and values embedded in the sacred texts. Another participant said that likhita japa, which is the writing of mantras, is also practiced commonly at the ashram. A mantra is a sacred word or phrase which is repeated by people during meditation (Chakraborty 2015, p. 1119). 


\subsection{Theme 4: Collaboration between Social Services and Faith-Based Organisations to Develop} Disadvantaged Communities

Participants said as follows:

"The social workers and child welfare workers pay us a visit but they do not come regularly ... we need them to come often and offer assistance to us".

"Social workers are needed in this community. Our community is large and spreads out far across the river ... sometimes only a few are coming and it is not enough for all of us to get to speak with her and share our problems".

"Members of the community come to the Ashram and discuss their issues with Swami when they have issues. Some of the youth come from broken homes and sometimes they stay at the Ashram when their family is experiencing problems".

Despite the acute need for social services in their community, participants expressed that social workers were absent in terms of service provision. McCartan et al. $(2018$, p. 2) indicated that individuals living in low-income neighbourhoods are often more likely to have inadequate access to formal services and lowered levels of social support. Walsh (2012, p. 361) noted that given that many faith-based organisations offer marriage and parenting skills workshops, youth mentoring and counseling, they can collaborate effectively with social work organisations to strengthen individual and family life and community well-being. Participants expressed that when they experience difficulties, they speak to the Spiritual Head of the Sarva Dharma Ashram who offers them counseling. If a partnership is developed between social service agencies and faith-based organisations, then leaders of faith organisations may refer such individuals and families for further support. A participant explained the need for social workers as follows:

"The social workers need to come and engage with the community as a group or as individuals to find out about the problems are we are having and together we all can come up with ideas on how to make Welbedacht a better place for us to live in ... they need to see what is going on for themselves".

As reflected in the excerpt, Lazarus et al. (2009, pp. 449-50) suggested that a "community counseling approach constitutes a form of psychological and social support integral to community social responses, and includes a variety of roles and activities that engage with the different levels of the social system, individuals, families and groups, organisations and institutions, specific communities, and society". This reflects the important role that social workers can play by collaborating with community partners and leaders of faith organisations in working synergistically to develop communities. Clarke (2013, p. 342) maintained that community ownership and participation in joint problem solving is crucial to interventions planned by social workers. Faith-based organisations play an important role in bridging the gap between social workers and community members in the planning and provision of services.

The salience of such collaborative work between social services, faith-based organisations and the community was highlighted by Twikirize et al. (2013, p. 57) who said that mobilizing people who are faced with the same problems, through the formation of groups, ideas and resources, can help towards problem solving, and development can be generated. By bringing the community together, the ashram has played an important role in advocating, mobilizing and empowering the community through its many project and programme initiatives as well as by bringing them to consider how to deal with their problems.

\section{Discussion}

The study reflected the salience of faith-based organisations in disadvantaged communities. Poverty and economic difficulties were the most pervasive and enduring challenge that youth and their families faced in Welbedacht. Their difficulties associated with poverty were characterized by a lack of access to food, education, unemployment, violence and substance abuse. These intermingling factors were highlighted by several scholars regarding the complexity of poverty and its effects on the well-being of people. The data emphasized 
the enduring presence of the Sarva Dharma Ashram in helping the community and families to transcend the hardships experienced. Service delivery remains a key aspect and requires intervention from stakeholders to develop the community on a broader perspective. In the absence of such basic services, those offered by the Sarva Dharma Ashram are crucial. Hinduism inspired faith-based organisations as key players in civil society who delve deep into community service as a form of seva. The study uncovered the major contributions with regards to community upliftment programmes which made a significant impact on youth and families living in Welbedacht. Furthermore, the presence of spiritually-based activities acted as a source of comfort for many members of the community. Spirituality fosters a sense of meaning, wholeness, harmony, and connection with others ranging from bonds to extended kinship and community networks, and to a unity with all life, nature, and the universe (Walsh 2012, p. 348). This highlights the importance of such organisations in disadvantaged communities and their efforts to empower and uplift youth and their families. However, an acute need for social services to exist in disadvantaged communities prevails. The collaboration between social services into faith-based organisations remains a critical point of interest which was not fully explored in the study. As such, an understanding of integration of social work into faith-based organisations is crucial to working successfully with such communities where social work intervention is most needed. Social service support from the government is limited and therefore requires greater involvement for partnerships to form to render such services to the Welbedacht community. These factors influence the development of marginalized communities.

\section{Limitations}

The role of faith-based organisations in promoting community and family well-being is important particularly in poor, disadvantaged communities. Although this case study focused on one faith-based organisation, it highlighted the potential for faith organisations who have grown within disadvantaged spaces with no infrastructure to support and capacitate its community members. Whilst the study did focus on one Hindu organisation, the focus was on how faith and particularly the presence of a faith organisation in a totally marginalized community can act to provide physical, psychological, educational and spiritual support to a poor community. Whilst prior research reflects that certain faithbased organisations discriminate and provide services on the condition that beneficiaries convert to their faith (Moyer et al. 2012, p. 29), this was not evident in the current study. Hence, despite the study being limited to one Hindu organisation, the intent was to highlight the role that faith-based organisations could play in supporting and developing a disadvantaged community.

\section{Conclusions}

Organisations "can only be understood in relation to the communities in which they are embedded" (Milofsky 2008, p. 203). Faith-based organisations that emerge and embed themselves in the life of a community at grassroots level enable the provision of socioeconomic and cultural services to the disadvantaged (Nwokoro 2017, p. 11). As was evident in the study, faith-based organisations are dynamic sources of services, resources, facilities and funding to communities (Placido and Cecil 2014, p. 80). The study found that faith remains a core motivator for the work that the organisation undertook, and it influenced the manner in which services were provisioned. The study reflected the transformational effect spirituality has had on distressed families. Of significance was the fact that this ashram was located within the epicenter of this marginalised community, thus creating an enduring comforting presence and an immediate resource that families could turn to when faced with a problem. Faith-based organisations have been recognised for their efforts in reaching the poorest at the grassroots level (Du Toit 2019, p. 1). In other contexts, most faith organisations exist in urban or developed services and provision services to those in marginalized communities. This organisation, however, exists within the milieu of the poor, acting as the only social system within this disadvantaged community. It highlights 
the potential for empowering and supporting poor communities through faith services. It is the element of faith that drives service to the poorest of humankind.

Author Contributions: Methodology, Y.G.; Supervision, R.B.; Writing—original draft, Y.G.; Writingreview \& editing, R.B. All authors have read and agreed to the published version of the manuscript.

Funding: Funding was received from the Health and Welfare Sector Education and Training Authority (HWSETA).

Institutional Review Board Statement: The study conducted was approved by Durban University of Technology's Institutional Research and Ethics Committee (IREC) with Ethics Clearance Number IREC 191/18.

Informed Consent Statement: Informed consent was obtained from all participants involved in the study.

Conflicts of Interest: The authors declare no conflict of interest.

\section{References}

Algate, Jane. 2011. Child and family focussed work in children's services. In Professional Development in Social Work: Complex Issues in Practice. Edited by Seden Janet, Sarah Matthews, Mick McCormick and Alun Morgan. New York: Routledge.

Ahsan, Amra, Maryyam Khan, and Roomana N. Siddiqui. 2012. The healing power of prayer in Islam. Indian Journal of Positive Psychology 3: 168-72.

Anand, Himani. 2014. Role of Prayer and Meditation in Enhancing Health and Well Being. Available online: https://shodhgangotri. inflibnet.ac.in/bitstream/123456789/2163/1/synopsis.pdf (accessed on 28 October 2019).

Apostolides, Anastasia. 2017. Adolescent spirituality with the support of adults. HTS Teologiese Studies/Theological Studies 73: 1-6. [CrossRef]

Beck, Guy. L. 2019. Sacred Music and Hindu Religious Experience: From Ancient Roots to the Modern Classical Tradition. Religions 10: 85. [CrossRef]

Benson, Peter. L., and Eugene C. Roehlkepartain. 2008. Spiritual development: A missing priority in youth development. New Directions for Youth Development 118: 13-28. [CrossRef] [PubMed]

Berger, Julia. 2003. Religious Nongovernmental Organizations: An Exploratory Analysis. Voluntas: International Journal of Voluntary and Nonprofit Organizations 14: 15-39. [CrossRef]

Bhagwan, Raisuyah. 2009. Creating sacred experiences for children as pathways to healing, growth and transformation. International Journal of Children's Spirituality 14: 225-34. [CrossRef]

Bhagwan, Raisuyah. 2012. Glimpses of ancient Hindu spirituality: Areas for integrative therapeutic intervention. Journal of Social Work Practice 26: 233-44. [CrossRef]

Bradshaw, Matt, and Christopher G. Ellison. 2010. Financial hardship and psychological distress: Exploring the buffering effects of religion. Social Science $\mathcal{E}$ Medicine 71: 196-204.

Bopp, Melissa, Benjamin L. Webb, and Elizabeth A. Fallon. 2012. Urban-rural differences for health promotion in faith-based organizations. Online Journal of Rural Nursing and Health Care 12: 51-63. [CrossRef]

Braun, Virginia, and Victoria Clarke. 2006. Using thematic analysis in psychology. Qualitative Research in Psychology 3: 1-41. [CrossRef]

Chakraborty, Smita. 2015. Prayer and Mantra as a Provenance of healing: A sociological analysis. SRJIS 3: 1118-25.

Cheon, Jeong Woong, and Edward R. Canda. 2010. The meaning and engagement of spirituality for positive youth development in social work. Families in Society 91: 121-26. [CrossRef]

Chima, Sylvester C. 2015. Religion politics and ethics: Moral and ethical dilemmas facing faith-based organizations and Africa in the 21st century-implications for Nigeria in a season of anomie. Nigerian Journal of Clinical Practice 18: S1-S7. [CrossRef] [PubMed]

Clarke, Matthew. 2013. Good works and God's work: A case study of Churches and community development in Vanuatu. Asia Pacific Viewpoint 54: 340-351. [CrossRef]

Clarke, Gerard, and Michael Jennings. 2008. Development, Civil Society and Faith-Based Organizations: Bridging the Sacred and the Secular. London: Palgrave Macmillan.

Cooper, Hannah Linton, Sabriya Linton, Danielle F. Haley, Mary E. Kelley, Emily F. Dauria, Conny C. Karnes, Zev Ross, Josalin Hunter-Jones, Kristen K. Renneker, Carlos del Rio, and et al. 2015. Changes in exposure to neighborhood characteristics are associated with sexual network characteristics in a cohort of adults relocating from public housing. AIDS and Behavior 19: 1-17. [CrossRef] [PubMed]

Coovadia, Hoosen, Rachel Jewkes, Peter Barron, David Sanders, and Diane McIntyre. 2009. The health and health system of South Africa: Historical roots of current public health challenges. The Lancet 374: 817-34. [CrossRef]

Crisp, Beth R. 2014. Social Work and Faith-Based Organizations. New York: Routledge.

Crowe, Sarah, Kathrin Cresswell, Ann Robertson, Guro Huby, Anthony Avery, and Aziz Sheikh. 2011. The case study approach. BMC Medical Research Methodology 11: 1-9. [CrossRef] [PubMed] 
De Wet, Nicole, Oluwaseyi Somefun, and Ndivhuwo Rambau. 2018. Perceptions of community safety and social activity participation among youth in South Africa. PLoS ONE 13: 1-11. [CrossRef]

Du Toit, Nadine Bowers. 2019. Does faith matter? Exploring the emerging value and tensions ascribed to faith identity in South African faith-based organisations. HTS Teologiese Studies/Theological Studies 75: 1-7.

Ebenezer, Megbowon, and Mushunje Abbyssinia. 2018. Livelihood diversification and its effect on household poverty in Eastern Cape Province, South Africa. The Journal of Developing Areas 52: 235-49. [CrossRef]

Furrow, James L., Pamela E. King, and Krystal White. 2004. Religion and positive youth development: Identity, meaning, and prosocial concerns. Applied Developmental Science 8: 17-26. [CrossRef]

Garland, Diana R., and Gaynor I. Yancey. 2012. Moving mountains: Congregations as settings for social work practice. In Christianity and Social Work: Readings on the Integration of Christian Faith and Social Work Practice. Botsford: North American Association of Christians in Social Work, pp. 331-36.

Glicken, Morley D. 2011. Social Work in the 21st Century: An Introduction to Social Welfare, Social Issues and the Profession. London: Sage Publications.

Graddy, Elizabeth. 2006. Faith-based versus secular providers ofsocial services-Differences in what, how, and where. Journal of Health and Human Services Administration 29: 309-335.

Green-Powell, Patricia A., Adriel A. Hilton, and Crystal L. Joseph. 2011. Creating Collaborative Partnership With Local Churches to Improve Academic Performance of K-12 Public Schools. Online Submission 8: 64-69.

Grut, Lisbet, Gubela Mji, Stine Hellum Braathen, and Benedicte Ingstad. 2012. Accessing community health services: Challenges faced by poor people with disabilities in a rural community in South Africa. African Journal of Disability 1: 1-7. [CrossRef]

Hafner, Craig. 2009. Strengthening the Role of Faith-Based Organizations in Human Resources for Health Initiatives. The Capacity Project. Available online: https://www.capacityproject.org/images/stories/files/legacyseries_8.pdf (accessed on 16 October 2019).

Harr, Cynthia R., and Gaynor I. Yancey. 2014. Social work collaboration with faith leaders and faith groups serving families in rural areas. Journal of Religion E Spirituality in Social Work: Social Thought 33: 148-62.

Heist, Dan, and Ram A. Cnaan. 2016. Faith-based international development work: A review. Religions 7: 19. [CrossRef]

Hlalele, Dipane. 2012. Psychosocial support for vulnerable rural school learners: In search of social justice! Journal for New Generation Sciences 10: 63-76.

Jacobs, Stephen. 2014. Inner peace and global harmony: Individual wellbeing and global solutions in the art of living. Culture Unbound 6: 873-89. [CrossRef]

James, Rick. 2011. Handle with care: Engaging with faith-based organisations in development. Development in Practice 21: 109-17. [CrossRef]

Johnsen, Sarah. 2014. Where's the 'faith' in 'faith-based' organisations? The evolution and practice of faith-based homelessness services in the UK. Journal of Social Policy 43: 413-30. [CrossRef]

Kagawa, Rose Calnin, Andrew Anglemyer, and Dominic Montagu. 2012. The scale of faith based organization participation in health service delivery in developing countries: Systemic review and meta-analysis. PLoS ONE 7: 1-8. [CrossRef]

Kalyani, K. Mehta. 2021. Spirituality: The Hindu perspective from a gerontologist's viewpoint. Journal of Religion, Spirituality $\mathcal{E}$ Aging 33: $127-38$.

Kaur, Jasmeet, and Deepty Gupta. 2013. Value education through religious scriptures: A secular approach for maintaining peace. International Journal of Peace, Education and Development 1: 25-30.

King, Pamela Ebstyne, and Chris J. Boyatzis. 2015. Religious and spiritual development. In Handbook of Child Psychology and Developmental Science, 7th ed. Edited by Lerner Richard M. New Jersey: Wiley \& Sons, pp. 975-1021.

Klostermaier, Klaus K. 2000. A Short History of Hinduism. New York: Simon and Schuster.

Kvarfordt, Connie L., and Kasha Herba. 2018. Religion and spirituality in social work practice with children and adolescents: A survey of Canadian practitioners. Child and Adolescent Social Work Journal 35: 153-67. [CrossRef]

Larson, Reed W., and Bic Ngo. 2017. Introduction to special issue: The importance of culture in youth programs. Journal of Adolescent Research 32: 3-10. [CrossRef]

Larson, Reed W., David M. Hansen, and Giovanni Moneta. 2006. Differing profiles of developmental experiences across types of organized youth activities. Developmental Psychology 42: 849-63. [CrossRef] [PubMed]

Hindu spirituality and healing practices. 2005, Laungani, Pittu. In Integrating Traditional Healing Practices into Counseling and Psychotherapy. Edited by Moodley Roy and William West. Thousand Oaks: Sage Publications, pp. 138-47.

Lazarus, Sandy, Donna Baptiste, and Mohamed Seedat. 2009. Community counselling: Values and practices. Journal of Psychology in Africa 19: 449-54. [CrossRef]

Letsela, Lebohang, and Kopano Ratele. 2009. I Am a tsotsi from Sophiatown, You Must Cure Yourself: Masculinity and Health Seeking Behaviours in South Africa. Cape Town and Johannesburg: MRC-UNISA Crime.

Leurs, Robert. 2012. Are faith-based organisations distinctive? Comparing religious and secular NGOs in Nigeria. Development in Practice 22: 704-20. [CrossRef]

Mampane, Johannes N. 2018. Exploring the "Blesser and Blessee" Phenomenon: Young Women, Transactional Sex, and HIV in Rural South Africa. SAGE Open 8: 1-9. [CrossRef] 
McCartan, Claire, Aine Morrison, Lisa Bunting, Gavin Davidson, and Jackie Mcllroy. 2018. Stripping the Wallpaper of Practice: Empowering Social Workers to Tackle Poverty. Social Sciences 7: 193. [CrossRef]

McLaughlin, Milbrey W. 2000. Community Counts: How Youth Organizations Matter for Youth Development. Washington, DC: Public Education Network.

Merriam, Sharan B. 2002. Introduction to qualitative research. Qualitative Research in Practice: Examples for Discussion and Analysis 1: 1-17.

Milofsky, Carl. 2008. Smallville: Institutionalizing Community in Twenty-First-Century America. Medford: Tufts University Press.

Monnickendam, Menachem, Chana Katz, and Shlomo Monnickendam. 2010. Social workers serving poor clients: Perceptions of poverty and service policy. British Journal of Social Work 40: 911-27. [CrossRef]

Moyer, Joanne M., A. John Sinclair, and Harry Spaling. 2012. Working for God and sustainability: The activities of faith-based organizations in Kenya. Voluntas: International Journal of Voluntary and Nonprofit Organizations 23: 959-92. [CrossRef]

Naidu, Maheshvari. 2013. Transnationalising the Sacred: The Yajna as Transnational 'Spectacle'? South Asian Survey 20: 137-49. [CrossRef]

Nishimuko, Mikako. 2009. The role of non-governmental organisations and faith-based organisations in achieving Education for All: The case of Sierra Leone. Compare 39: 281-95. [CrossRef]

Nithyananda, Paramahamsa. 2015. Bhagavad Gita Decoded. San Diego: Nithyananda University Press.

Nordtvedt, Mark, and Larry S. Chapman. 2011. Health promotion in faith-based institutions and communities. American Journal of Health Promotion 25: TAHP1-TAHP12. [CrossRef]

Nwokoro, Chioma V. 2017. Assessing the distinctiveness of faith based organizations in the development sector in Nigeria. Journal of Humanities and Social Policy 3: 1-16.

Oghenekohwo, Jonathan E., and Young D. Tonunarigha. 2019. Empowerment Programmes of Faith-Based Organisations (FBOs) and Socio-economic Well-being of Members in Yenagoa Community, Bayelsa State, Nigeria. International Journal of Education and Literacy Studies 7: 192-98. [CrossRef]

Olarinmoye, Omobolaji Ololade. 2012. Faith-based organizations and development: Prospects and constraints. Transformation 29: 1-14. [CrossRef]

Pandey, Aranika, Prakash Paudel, and Luna Paudel. 2011. Scenario of health camps in Nepal. Journal of Nepal Health Research Council 9: $86-88$.

Pandya, Samta P. 2016. Sociality and guru-led movements: Interplay of social issues, action and social service. Current Sociology 64: 775-93. [CrossRef]

Pandya, Samta P. 2017. Food, faith, social service and institution building: The Annamrita programme of the Hare Krishna movement in India. Religion, State $\mathcal{E}$ Society 45: 4-22.

Piraino, Andrew, Gail Krema, Shannon M. Williams, and Joseph R. Ferrari. 2014. Hour of HOPE: A spiritual prayer program for homeless adults. Universal Psychology 2: 1-4. [CrossRef]

Placido, Nicholas, and David Cecil. 2014. Implementing best practices for needs assessment and strategic planning systems: Social work and faith based organization collaboration-A case study. Social Work and Christianity 41: 79-94.

Power, Madeleine, Bob Doherty, Neil Small, Simon Teasdale, and Kate E. Pickett. 2017. All in it together? Community food aid in a multi-ethnic context. Journal of Social Policy 46: 447-71. [CrossRef]

Roth, Jodie L., and Jeanne Brooks-Gunn. 2017. Evaluating youth development programs. Applied Developmental Science 20: 188-202. [CrossRef]

Seden, J. 2011. The use of self and relationship: Swimming against the tide? In Professional Development in Social Work: Complex Issues in Practice. Edited by Seden Janet, Sarah Matthews, Mick McCormick and Alun Morgan. New York: Routledge.

Sekhampu, Tshediso J. 2012. Poverty in a South African township: The case of Kwakwatsi. African Journal of Business Management 6: 9504-09.

Sewajyoti. 2020. Concept of Sewa. Available online: https:/ / sewajyoti.com/CONCEPT-OF-SEWA (accessed on 15 June 2021 ).

Shisana Olive, Labadarios Demetre, Rehle Thomas, Simbayi Leickness, Zuma Khangelani, Dhansay Ali, Reddy Priscilla, Parker Whadi-ah, Hoosain Ebrahim, Naidoo Pamela, Derek Davids Yul, and et al. 2013. South African National Health and Nutrition Examination Survey (SANHANES-1). Cape Town: HSRC Press.

Singh, Ajay Pratap. 2016. Role and importance of "Guru" in Indian spiritual tradition. Sai Om Journal of Arts and Education 3: 76-79.

Sookrajh, Reshma. 2006. Religious giving in south africa-A hindu perspective. Nidan: International Journal for Indian Studies $2006: 18$.

Spray, Carolyn, and Beverley Jowett. 2012. Social Work Practice with Children and Families. London: Sage Publications.

Srivastava, Chittiji, Vishal Dhingra, Anupam Bhardwaj, and Alka Srivastava. 2013. Morality and moral development: Traditional Hindu concepts. Indian Journal of Psychiatry 55: S283. [CrossRef]

Strassburg, Sabine, Sarah Meny-Gilbert, and Bev Russell. 2010. Left Unfinished: Temporary Absence and Drop-Out from South African Schools. Findings from the Access to Education Study. Johannesburg: Social Surveys Africa and Centre for Applied Legal Studies, vol. 2.

Swami, Mukundananda. 2014. Bhagavad Gita-The Song of God. Available online: https://www.holy-bhagavad-gita.org/chapter/14 (accessed on 15 June 2021).

Tadros, Mariz. 2010. Faith-Based Organizations and Service Delivery: Some Gender Conundrums. Geneva: United Nations Research, Geneva: Institute for Social Development. 
Thobejane, Tsoaledi, and Raymond Raselekoane. 2017. Probing alcohol abuse amongst the youth of Musina Community in Limpopo Province of South Africa. Journal of Studies of Tribes and Tribals 15: 94-102.

Twikirize, Janestic Mwende, Narathius Asingwire, Julius Omona, Rosalind Lubanga, and Agatha Kafuko. 2013. The Role of Social Work in Poverty Reduction and the Realisation of Millennium Development Goals in Uganda. Kampala: Fountain Publications.

UNICEF. 2012. Partnering with Religious Communities for Children; New York: UNICEF. Available online: https://www.unicef.org/about/ partnerships/files/Partnering_with_Religious_Communities_for_Children_\%28UNICEF\%29.pdf (accessed on 23 May 2020).

UNFPA (United Nations Population Fund). 2015. Global Forum of Faith-Based Organisations for Population and Development. Available online: https:/ / www.unfpa.org/sites/default/files/pub-pdf/global_forums_fbo.pdf (accessed on 23 May 2020).

Walsh, Froma. 2012. Normal Family Processes: Growing Diversity and Complexity, 4th ed. New York: Guilford Publications.

Xaba, Thokozani. 2016. From public-private partnerships to private-public stick'em ups! NGOism, neoliberalism, and social development in post-apartheid South Africa. International Social Work 58: 1-11.

Yancey, Gaynor, and Kelly Atkinson. 2004. The impact of caring in faith-based organizations: What participants say. Social Work E Christianity 31: 254-66. 